\title{
Urban-rural gradients in soil nutrients beneath Chinese pine (Pinus tabulaeformis Carr.) are affected by land-use
}

\section{Yuebo Su}

RCEES: Research Centre for Eco-Environmental Sciences Chinese Academy of Sciences

\section{Bowen Cui}

RCEES: Research Centre for Eco-Environmental Sciences Chinese Academy of Sciences

\section{Zhiyun Ouyang}

RCEES: Research Centre for Eco-Environmental Sciences Chinese Academy of Sciences

\section{Xiaoke Wang ( $\nabla$ wangxk@rcees.ac.cn )}

Research Center for Eco-Environmental Sciences, Chinese Academy of Sciences

https://orcid.org/0000-0002-2421-3970

\section{Research Article}

Keywords: Chinese pine, Land-use types, Soil nutrients, Urban-rural gradients

Posted Date: February 23rd, 2021

DOl: https://doi.org/10.21203/rs.3.rs-183584/v1

License: (9) This work is licensed under a Creative Commons Attribution 4.0 International License. Read Full License

Version of Record: A version of this preprint was published at Urban Ecosystems on January 26th, 2022. See the published version at https://doi.org/10.1007/s11252-022-01205-y. 


\section{Abstract}

Urban-rural gradients of soil nutrients may be affected by many factors including land use, vegetation cover, and management. In this study, we investigated soil nutrients along urban-rural gradients beneath Chinese pine (Pinus tabulaeformis Carr.) in parks, neighborhoods and roadsides in Beijing, China. Soil levels of organic carbon, calcium, and magnesium are significantly higher in neighborhoods and parks than in roadsides. Soil nitrate-nitrogen levels are higher in neighborhoods than in roadsides. Soil magnesium levels are higher in neighborhoods than in parks. Interestingly, soil moisture, nitrate-nitrogen, calcium, magnesium, and available phosphorus and potassium all decreased in parks along the urban to rural gradient. Soil available phosphorus also declined along urban-rural gradients in neighborhoods. Thus, land use plays an important role in modifying urban-rural gradients of soil nutrients.

\section{Introduction}

Urbanization directly or indirectly affects the biological, physical and chemical properties of soils and the processes that affect them (Pouyat et al. 2010; Herrmann et al. 2018). Gradients in soil properties have been studied at the scales of patches (Jenerette et al. 2010), cities (Pouyat et al. 2006; Pouyat et al. 2010), regions (Pouyat et al. 2007; Li et al. 2013), and globally (Pouyat et al. 2006). The urban-rural gradient paradigm characterizes variation in soils with respect to the degree of urbanization as measured by land-use intensity (Su et al. 2019), style of land management (Mao et al. 2014), particular microenvironments (Liu et al. 2007), and/or the flora and fauna that compose soils (Zhu and Carreiro 1999; Zhao et al. 2010). This paradigm is considered useful for describing effects of urbanization on soil nutrients due to its simplicity and effectiveness (Bennett 2003; Vasenev et al. 2013; Chen et al. 2014; Meng et al. 2018).

Previous studies have described how urban-rural gradients of soil nutrients are influenced by many factors including the geographical locations of study areas (Bennett 2003; Li et al. 2013), soil properties and depths (Baxter et al. 2002; Vasenev et al. 2013), land-use types (Bennett 2003; Foti et al. 2017), vegetation types (Zhao et al. 2007), and how the land is managed (Foti et al. 2017). Differences in management practice, soil history, the amounts and nutrient content of leaf litter (reflecting vegetation type), and the depth and density of plant roots can all affect the soil properties and thus the direction and slope of urban-rural gradients in these (Zhao et al. 2007; Lorenz and Lal 2009; Pouyat et al. 2010; Foti et al. 2017). Zhao et al. (2007) found that available phosphorus differs among soils supporting different crop or vegetable types, weakening the urban-rural gradient of available phosphorus in Nanjing, China. Foti et al. (2017) reported a similar trend: although physical and chemical properties of woodland soils varied along urban-rural gradients, such gradients were attenuated under lawns where soils are more actively managed, e.g., by regular fertilization.

Studies of the same city sometimes differ in which urban-rural gradients they show, even for the same soil nutrient (Table 1). To obtain more consistent results, some researchers control either for land-use type or vegetation type as they explore urban-rural gradients in soil nutrients (Pouyat et al. 1995; Bennett 2003; 
Kaye et al. 2008). In Phoenix, USA, Davies and Hall (2010) found that controlling for differences in landuse type (desert yards) but not in vegetation type reduces urban-rural gradients in soil moisture, organic matter and inorganic nitrogen. In New York, USA, Zhu and Carreiro (1999), Baxter et al. (2002), and Lovett et al. (2000) did the opposite, controlling for variation in vegetation type (looking only at oak stands) but not in land-use type and found the opposite result, namely increased urban-rural gradients in soil ammonium-nitrogen and nitrate-nitrogen (Table 1). Controlling for land-use and vegetation types thus appears to improve the precision with which we can assess urban-rural gradients in soil nutrients, even as we remain uncertain about just how land-use and vegetation affect these gradients. 
Table 1

Urban-rural gradients of soil nutrients

\begin{tabular}{|c|c|c|c|c|}
\hline Location & Land-use types & References & $\begin{array}{l}\text { Soil } \\
\text { nutrients } \\
\text { [2] }\end{array}$ & $\begin{array}{l}\text { Urban-rural } \\
\text { gradients }\end{array}$ \\
\hline \multirow{5}{*}{$\begin{array}{l}\text { Beijing, } \\
\text { China }\end{array}$} & \multirow{5}{*}{$\begin{array}{l}\text { Neighborhood, park, roadside, industrial, } \\
\text { institutional, road greenbelt, forest }\end{array}$} & \multirow{5}{*}{$\begin{array}{l}\text { (Mao et al. } \\
2014)\end{array}$} & SM & Increase \\
\hline & & & SOC & Increase \\
\hline & & & $\mathrm{TN}$ & Increase \\
\hline & & & AP & Increase \\
\hline & & & AK & Increase \\
\hline \multirow{2}{*}{$\begin{array}{l}\text { Hefei, } \\
\text { China }\end{array}$} & \multirow[t]{2}{*}{ Street, campus, park } & \multirow{2}{*}{$\begin{array}{l}\text { (Zhang et } \\
\text { al. 2010) }\end{array}$} & $\mathrm{NH} 4-\mathrm{N}$ & Increase \\
\hline & & & NO3-N & Decrease \\
\hline \multirow[t]{4}{*}{$\begin{array}{l}\text { Nanjing, } \\
\text { China }\end{array}$} & $\begin{array}{l}\text { Neighborhood, park, roadside, square, } \\
\text { campus, vegetable garden }\end{array}$ & $\begin{array}{l}\text { (Yuan et al. } \\
\text { 2007) }\end{array}$ & TP & Decrease \\
\hline & \multirow{3}{*}{$\begin{array}{l}\text { Neighborhood, park, roadside, industrial, } \\
\text { agricultural, traffic, municipal, others }\end{array}$} & \multirow{3}{*}{$\begin{array}{l}\text { (Zhao et al. } \\
\text { 2007) }\end{array}$} & TP & No change \\
\hline & & & AK & Decrease \\
\hline & & & TK & Increase \\
\hline \multirow{4}{*}{$\begin{array}{l}\text { Nanchang, } \\
\text { China }\end{array}$} & \multirow[t]{4}{*}{ NA ${ }^{[1]}$} & \multirow{4}{*}{$\begin{array}{l}\text { (Chen et al. } \\
\text { 2014) }\end{array}$} & $\mathrm{NH} 4-\mathrm{N}$ & Increase \\
\hline & & & NO3-N & Decrease \\
\hline & & & AP & Decrease \\
\hline & & & TP & Decrease \\
\hline $\begin{array}{l}\text { Hangzhou, } \\
\text { China }\end{array}$ & Residential, agricultural, commercial & $\begin{array}{l}\text { (Zhang } \\
\text { 2004) }\end{array}$ & TP & Decrease \\
\hline \multirow{2}{*}{$\begin{array}{l}\text { Hubei, } \\
\text { China }\end{array}$} & \multirow[t]{2}{*}{ Neighborhood, park, roadside } & \multirow{2}{*}{$\begin{array}{l}\text { (Li et al. } \\
\text { 2013) }\end{array}$} & AP & Increase \\
\hline & & & SOM & Increase \\
\hline $\begin{array}{l}\text { Chengdu, } \\
\text { China }\end{array}$ & Neighborhood, park, traffic, industrial & $\begin{array}{l}\text { (Li et al. } \\
2018)\end{array}$ & TP & Decrease \\
\hline \multirow{3}{*}{$\begin{array}{l}\text { New York, } \\
\text { USA }\end{array}$} & \multirow[t]{3}{*}{ NA } & \multirow{2}{*}{$\begin{array}{l}\text { (Zhu \& } \\
\text { Carreiro } \\
\text { 1999) }\end{array}$} & $\mathrm{NH} 4-\mathrm{N}$ & No change \\
\hline & & & NO3-N & Decrease \\
\hline & & $\begin{array}{l}\text { (Pouyat et } \\
\text { al. 2002) }\end{array}$ & SOC & Decrease \\
\hline
\end{tabular}

${ }^{[1]} \mathrm{NA}$ indicated no data available; ${ }^{[2]}$ The abbreviations of soil variables are shown in Appendix. 


\begin{tabular}{|c|c|c|c|c|}
\hline Location & Land-use types & References & $\begin{array}{l}\text { Soil } \\
\text { nutrients } \\
\text { [2] }\end{array}$ & $\begin{array}{l}\text { Urban-rural } \\
\text { gradients }\end{array}$ \\
\hline & & \multirow{3}{*}{$\begin{array}{l}\text { (Baxter et } \\
\text { al. 2002) }\end{array}$} & $\mathrm{NH} 4-\mathrm{N}$ & Increase \\
\hline & & & NO3-N & No change \\
\hline & & & AP & Increase \\
\hline & \multirow{4}{*}{$\begin{array}{l}\text { Park, field station, nature preserve, } \\
\text { environmental research organization }\end{array}$} & \multirow{4}{*}{$\begin{array}{l}\text { (Lovett et } \\
\text { al. 2000) }\end{array}$} & $\mathrm{NH} 4-\mathrm{N}$ & Decrease \\
\hline & & & NO3-N & Decrease \\
\hline & & & $\mathrm{Ca}$ & Decrease \\
\hline & & & $\mathrm{Mg}$ & Decrease \\
\hline \multirow{6}{*}{$\begin{array}{l}\text { Phoenix, } \\
\text { USA }\end{array}$} & \multirow{2}{*}{$\begin{array}{l}\text { Desert, neighborhood, industrial, river gravel, } \\
\text { agriculture }\end{array}$} & \multirow{2}{*}{$\begin{array}{l}\text { (Hope et al. } \\
\text { 2005) }\end{array}$} & $\mathrm{NH} 4-\mathrm{N}$ & No change \\
\hline & & & NO3-N & No change \\
\hline & \multirow[t]{4}{*}{ Desert } & \multirow{4}{*}{$\begin{array}{l}\text { (Davies \& } \\
\text { Hall 2010) }\end{array}$} & SM & Decrease \\
\hline & & & SOM & Decrease \\
\hline & & & $\mathrm{NH} 4-\mathrm{N}$ & Decrease \\
\hline & & & NO3-N & Decrease \\
\hline Dane, USA & Neighborhood & $\begin{array}{l}\text { (Bennett } \\
\text { 2003) }\end{array}$ & TP & No change \\
\hline $\begin{array}{l}\text { London, } \\
\text { England }\end{array}$ & NA & $\begin{array}{l}\text { (Meng et al. } \\
\text { 2018) }\end{array}$ & TP & Decrease \\
\hline $\begin{array}{l}\text { Moscow, } \\
\text { Russian }\end{array}$ & Industrial, residential, recreational & $\begin{array}{l}\text { (Vasenev et } \\
\text { al. 2013) }\end{array}$ & soc & Decrease \\
\hline
\end{tabular}

We studied urban-rural gradients in soil nutrients in Beijing, China, to answer two questions: (1) How do soil nutrients differ among different land-use types? (2) Are there clear urban-rural gradients in soil nutrients and do these differ among land-use types? Neighborhoods, parks, and roadsides are major land uses in both urban and rural areas in Beijing, China (Zhao 2010; Kuang 2012). To control for the influence of vegetation type on soil nutrients along the urban-rural gradient, we investigated only sites covered by one vegetation type: Chinese pine (Pinus tabulaeformis Carr.). This coniferous tree is endemic to northern China and a dominant species in the region. It is widely planted in both urban and rural areas of Beijing because of its high esthetic value and its ability to thrive in harsh habitats (Zhao 2010) (http://www.iplant.cn/info/Pinus\%20tabuliformis?t=z). We measured soil nutrients beneath Chinese pine 
in 15 neighborhoods, 25 parks and 24 roadsides that spanned broad urban-rural gradients, providing a clean design for a "natural" experiment with three "treatments" (Diamond 1983).

\section{Methods}

\subsection{Study sites}

This study was conducted in Beijing $\left(39^{\circ} 28^{\prime}-41^{\circ} 25^{\prime} \mathrm{N}, 115^{\circ} 25^{\prime}-117^{\circ} 30^{\prime} \mathrm{E}\right)$, the largest metropolis of northern China. The city has temperate humid monsoonal continental climate with a mean annual temperature of $11-12^{\circ} \mathrm{C}$ and mean annual precipitation of $500 \mathrm{~mm}$. Dominant native soils in Beijing are cinnamon soils and fluvo-aquic soils with parent materials consisted of weathering rocks and loose quaternary sediment (Liu et al. 2016).

In July 2016, we set up a south-north transect running through the city center (Fig. 1). The transect spans quickly urbanizing regions as well as rural areas belonging to Beijing administratively (Mao et al. 2014; Peng et al. 2016). Along this transect, we studied soils in Chinese pine forests located in 15 neighborhoods, 25 parks and 24 roadsides (Fig. 1). We had two considerations in choosing these sites: (1) the cover of Chinese pine forests was more than $100 \mathrm{~m}^{2}$; (2) sites were spaced at least 1-km apart. These Chinese pine stands averaged 22 years old. The average height and diameter at breast height were $5.85 \mathrm{~m}$ and $16.62 \mathrm{~cm}$, respectively.

\subsection{Soil sampling and soil nutrient analysis}

At each site, we sampled surface soils $(0-20 \mathrm{~cm})$ in four plots then mixed these to obtain a combined sample for analysis. The soil samples were oven-dried to constant weight at $105^{\circ} \mathrm{C}$ for $72 \mathrm{~h}$. Percent soil moisture (SM, Appendix) was calculated from the weight difference between wet and dry soil per unit dry soil (Lu 2000). We measured soil organic carbon (SOC) using the dilution heat $\mathrm{K}_{2} \mathrm{Cr}_{2} \mathrm{O}_{7}$ oxidation volumetric method (Lu 2000; Yu et al. 2010). Soil ammonium-nitrogen (NH4-N) and nitrate-nitrogen (NO3$\mathrm{N})$ were extracted using $1.0 \mathrm{~mol} / \mathrm{L}$ potassium chloride and then analyzed via flow injection analysis (Lachat QuikChem, Lachat Instruments, Colorado, USA) (Lu 2000; Yu et al. 2010). Soil available phosphorus (AP) was derived from samples digested with $0.5 \mathrm{~mol} / \mathrm{L} \mathrm{pH} 8.5 \mathrm{NaHCO}_{3}$ and analyzed using Mo-Sb colorimetry (Lu 2000; Yu et al. 2010). For soil available potassium (AK), we digested samples with $1.0 \mathrm{~mol} / \mathrm{L} \mathrm{pH} 7 \mathrm{CH}_{3} \mathrm{COONH}_{4}$ and determined concentrations using ICP-OES (Prodigy, Leeman, USA) (Lu 2000; Yu et al. 2010). Soil calcium concentration (Ca) and magnesium concentration (Mg) were determined using ICP-OES (Prodigy, Leeman, USA), following closed $\mathrm{HNO}_{3} / \mathrm{HCL} / \mathrm{HF}$ digestion in a microwave oven (Chen et al. 1999).

\subsection{Data analysis}

All statistical analyses were performed using the $\mathrm{R}$ language ( $\mathrm{R}$, version 3.5, http://www.R-project.org). Because NO3-N, AP, AK, Ca and Mg were not highly skewed, we normalized their distributions using a $\log _{10}$ transformation before analysis. We first used ANOVA models to test whether soil properties varied 
among the land-use types. We used the Tukey's HSD test to compare resulting estimated differences in soil property values between particular land-use types. We adjusted the $\mathrm{p}$ values from these Tukey-HSD tests using the Benjamini and Hochberg's false rate of discovery method in the 'multcomp' package in $\mathrm{R}$ (Benjamini and Hochberg 1995). We then applied simple linear regression models usimg the 'Im' function in $\mathrm{R}$ to test for urban-rural gradients in soil properties.

\section{Results}

\subsection{Soil nutrient contents among land-use types}

Land-use types differed in soil nutrient levels in these Chinese pine stands. In particular, levels of SOC, Ca and $\mathrm{Mg}$ under Chinese pines growing within neighborhoods and parks were appreciably higher than levels of these nutrients in roadside areas ( $P<0.01$, Fig. 2 ). Neighborhoods had $62 \%, 113 \%$, and $168 \%$ more SOC, $\mathrm{Ca}$, and $\mathrm{Mg}$, respectively, than roadsides while parks had $36 \%, 70 \%$, and $81 \%$ more. Neighborhoods also had $47 \%$ higher levels of soil NO3-N than roadsides $(P<0.05$, Fig. 2D) and $168 \%$ higher soil Mg than parks $(P<0.01$, Fig. $2 \mathrm{H})$.

\subsection{Urban-rural gradients in soil nutrients}

Conspicuous and consistent urban-rural gradients in soil nutrients exist in Beijing. Overall, and in all particular cases that were significant, nutrient levels decline from urban to rural sites across park lands. SM (slope: $-0.630 ; R^{2}$ : 0.52; P. < 0.01; Fig. 3A), NO3-N (-0.027; 0.34; < 0.01; Fig. 3D), AP (-0.033; 0.29; < 0.01; Fig. 3E), AK (-0.025; 0.50; < 0.01; Fig. 3F), Ca $(-0.036 ; 0.41 ;<0.01 ;$ Fig. 3G) and Mg $(-0.042 ; 0.31 ;<$ 0.01 ; Fig. $3 \mathrm{H})$ significantly decreased from urban to rural sites for parks. Only soil AP $(-0.044 ; 0.41 ;<0.01)$ significantly decreased from urban to rural sites in neighborhoods (Fig. 3E).

\section{Discussion}

\subsection{Effects of land-use types on soil nutrient contents}

Soils under different land-use types were modified by anthropogenic disturbances to different degrees (Pouyat et al. 2007; Mao et al. 2014; Li et al. 2018). In our study, soil levels of SOC, Ca and Mg in neighborhoods and parks were higher than that in roadsides (Fig. 2) as was soil NO3-N in neighborhoods (Fig. 2D). Similarly, SOC levels in neighborhoods were higher in Baltimore, USA (Pouyat et al. 2002) and Phoenix, USA (Davies and Hall 2010). Soil Ca levels in neighborhoods were higher in Beijing, China than in other land-use types (Ma 2007). Neighborhoods and parks typically experience higher inputs of soil nutrients than roadsides as city dwellers often deliberately apply fertilizer and inadvertent fertilization occurs from pets and livestock (Hope et al. 2005; Lorenz and Lal 2009). Neighborhoods and parks are designed as mostly artificial landscapes with high plant diversity for aesthetic and recreational value while still retaining some residual vegetation (Sharpe et al. 1986; Li et al. 2006; Zhao 2010). To sustain this vegetation, more active management occurs in most neighborhoods and parks than in roadsides. 
This includes more frequent irrigation and the addition of chemical fertilizers (Mao et al. 2014; Li et al. 2018).

Some of these gradients are element-specific, suggesting that the mechanisms that may account for them are, too. Soil organic carbon, for example, may be related to soil age. During the construction of neighborhoods and parks, some soils in these areas were preserved without being moved. Once built, neighborhoods and parks experience little soil disturbance. In contrast, old and broken roads are frequently rebuilt, meaning that soils in these areas may be frequently renewed or disturbed. Thus, while SOC could accumulate with age in neighborhoods and parks, this is less likely in roadsides (Mao et al. 2014; Bae and Ryu 2015). We also observed that soil Ca was higher in neighborhoods and parks. This may reflect that fact that more buildings and recreational facilities in these areas use construction materials like bricks, cement, and concrete with abundant Ca (Pouyat et al. 2007; Mao et al. 2014).

Others have sometimes documented results that differ from ours. Mao et al. (2014) found higher levels of soil organic carbon in roadsides than in neighborhoods and parks in Beijing. It is possible that in their study, the effects of land-use were confounded with the effects of vegetation type. Their study included several vegetation types, so unbalanced sampling among these might lead to the inconsistent result (Jackson et al. 2002; Zhao 2010; Guo et al. 2018; Liu et al. 2018).

\subsection{Effects of land-use types on urban-rural patterns of soil nutrients}

Urbanization tends to degrade the biophysical environment while not diminishing soil nutrients. In this study, SM, NO3-N, AP, AK, Ca, and Mg were all higher in urban than in rural park lands (Fig. 3). Previous studies also found higher soil nutrients in urban areas than in rural areas, such as for soil NO3-N in New York, America (Zhu and Carreiro 2004), soil AP in Beijing, China (Mao et al. 2014), soil AK in Nanjing, China (Zhao et al. 2007), and soil Ca in New York, America (Pouyat et al. 2008).

Monotonic increases in soil nutrients toward city centers could reflect several factors. First, if construction waste following the construction of buildings in urban areas was mixed into soils, concrete and cement could elevate soil Ca, Mg, TP and TK (Pouyat et al. 2007; Mao et al. 2014; Li et al. 2018). Second, intensive vegetation management practices in urban areas could increase soil nutrients, such as frequent irrigation with eutrophic reclaimed water and chemical fertilization increasing SM, SOC, TN and TP (Hope et al. 2005; Mao et al. 2014). Third, some indirect influence by the invasion of exotic earthworm (Baxter et al. 2002; Pouyat et al. 2002; Phillips et al. 2019), and/or by high soil temperatures due to heat island effect (Pouyat et al. 2010; Li et al. 2013) could facilitate the accumulation of soil nutrients by accelerating nutrient cycling.

An interesting result of this study is that the urban-rural gradients of soil nutrients differed among landuse types. Six out of eight nutrients decline along urban-rural gradients across parks, but only one nutrient did so for neighborhoods and none showed this trend among roadside pine stands (Fig. 3). The significant gradient of soil nutrients across parks probably reflects differences in their history and 
management intensity between urban and rural areas. The spatial pattern of Beijing, the capital of China, has changed little over the past 1000 years except for expanded built-up areas and denser populations. Most parks in the inner city are historical sites and little altered over their long history (Li et al. 2006). Park soils along urban-rural gradients might thus reflect an age gradient. Most parks in the city center, such as Yuetan Park (built in 1530) and Jingshan Park (1928), are far older than parks away from city center, such as Olympic Forest Park (2008) and Banta Country Park (2011). These older parks in the city center were usually better managed and preserved. However, younger parks in the outer city have short histories and tend to be managed less as they serve fewer people spread over a relatively large area. In Beijing, neighborhoods are usually managed by property management companies, not directly by various house owners (Gao and Asami 2011; Wang et al. 2015). This may lead to homogeneous management measures (e.g., fertilization and irrigation) across neighborhoods. This may contribute to low variability of soil nutrients in neighborhoods along urban-rural gradients (Bennett 2003; Davies and Hall 2010; Polsky et al. 2014; Wang et al. 2015). Less change in soil TP across residential zones along urban-rural gradients has also been reported in Dane Country, Wisconsin, America (Bennett 2003).

Unlike parks and neighborhoods, roadsides are frequently in the process of being rebuilt to meet increased traffic congestion or to cater to modern standards of design (Mao et al. 2014; Mo et al. 2017). This results in little difference in the age of roadside soils along the urban-rural gradient, perhaps explaining why significant urban-rural gradients in soil nutrients do not occur among roadsides (Foti et al. 2017).

This investigation showed that controlling for vegetation (by only sampling sites with Chinese pine cover) exposed urban-rural gradients in soil nutrients that differ among the three land use types we studied. Our analyses, however, ignored other factors that could influence soil nutrients along urban-rural gradients. These include biophysical factors such as temperature and moisture (Fang et al. 2005), impervious surfaces (Raciti et al. 2012), air quality (Gregg et al. 2003; Loya et al. 2003), nitrogen deposition (Phoenix et al. 2012), plants and soil fauna (Pouyat et al. 2010), and human disturbance (Bowd et al. 2019). Any of these factors could potentially influence the response of soil nutrients to urban-rural gradients. While we examined effects of land-use type on the urban-rural gradient in soil nutrients in Beijing, these additional factors should be investigated to improve our understanding of the forces driving urban-rural gradients in soil nutrients.

\section{Conclusions}

Many factors influence soil nutrient levels, limiting the ability of other studies to find clear and consistent urban-rural gradients in soil nutrients. Here, we controlled for vegetation cover by restricting our study to one cover type (pine forests). We also controlled for land use by examining multiple replicates of three land uses dispersed along the urban-rural gradient, allowing a balanced ("natural") experimental design. These controls allowed us to detect and characterize conspicuous urban-rural gradients in soil nutrients primarily in parklands. This probably reflects differences in history and management intensity for parks located in urban vs. rural areas. We also found urban-rural gradients in soil nutrients to be element- 
specific. This might reflect particular management practices (such as fertilization) or effects from human constructions (the use of cement and minerals). The former influences SOC, soil NO3-N and AK, while the latter influences soil $\mathrm{Ca}$ and $\mathrm{Mg}$. Because human activities are strongly related to land use, it is important to control for land-use when seeking to study the urban-rural gradients in soil nutrients.

\section{Declarations}

\section{Acknowledgements}

This study was supported by the National Natural Science Foundation of China (71533005 and 41571053). We sincerely thank Donald $M$. Waller for his suggestion of revision and polishing language. Also, we thank the editors and reviewers for their valuable comments, which improved the manuscript.

\section{Ethics declarations}

\section{Ethics approval and consent to participate}

Not applicable.

\section{Consent for publication}

The authors consent to the terms for publication as stated by the journal and its publisher.

\section{Competing interests}

The authors have no conflicts of interest to declare.

\section{References}

Bae, J. and Ryu, Y. (2015). Land use and land cover changes explain spatial and temporal variations of the soil organic carbon stocks in a constructed urban park. Landscape and Urban Planning, 136, 57-67.

Baxter, J.W., Pickett, S.T., Dighton, J. and Carreiro, M.M. (2002). Nitrogen and phosphorus availability in oak forest stands exposed to contrasting anthropogenic impacts. Soil Biology and Biochemistry, 34, 623633.

Benjamini, Y. and Hochberg, Y. (1995). Controlling the false discovery rate: a practical and powerful approach to multiple testing. Journal of the Royal statistical society: series B (Methodological), 57, 289300.

Bennett, E.M. (2003). Soil phosphorus concentrations in Dane County, Wisconsin, USA: an evaluation of the urban-rural gradient paradigm. Environmental Management, 32, 476-487. 
Bowd, E.J., Banks, S.C., Strong, C.L. and Lindenmayer, D.B. (2019). Long-term impacts of wildfire and logging on forest soils. Nature Geoscience, 12, 113.

Chen, F.S., Yavitt, J. and Hu, X.-F. (2014). Phosphorus enrichment helps increase soil carbon mineralization in vegetation along an urban-to-rural gradient, Nanchang, China. Applied soil ecology, 75, 181-188.

Chen, M., Ma, L.Q. and Harris, W.G. (1999). Baseline concentrations of 15 trace elements in Florida surface soils. Journal of Environmental Quality, 28, 1173-1181.

Davies, R. and Hall, S.J. (2010). Direct and indirect effects of urbanization on soil and plant nutrients in desert ecosystems of the Phoenix metropolitan area, Arizona (USA). Urban Ecosystems, 13, 295-317.

Diamond, J.M. (1983). Ecology: Laboratory, field and natural experiments. Nature, 304, 586-587.

Fang, C., Smith, P., Moncrieff, J.B. and Smith, J.U. (2005). Similar response of labile and resistant soil organic matter pools to changes in temperature. Nature, 433, 57.

Foti, L., Dubs, F., Gignoux, J., Lata, J.C., Lerch, T.Z., Mathieu, J. et al. (2017). Trace element concentrations along a gradient of urban pressure in forest and lawn soils of the Paris region (France). Science of the Total Environment, 598, 938-948.

Gao, X. and Asami, Y. (2011). Preferential size of housing in Beijing. Habitat International, 35, 206-213.

Gregg, J.W., Jones, C.G. and Dawson, T.E. (2003). Urbanization effects on tree growth in the vicinity of New York City. Nature, 424, 183.

Guo, P., Su, Y., Wan, W., Liu, W., Zhang, H., Sun, X. et al. (2018). Urban Plant Diversity in Relation to Land Use Types in Built-up Areas of Beijing. Chinese geographical science, 28, 100-110.

Herrmann, D.L., Schifman, L.A. and Shuster, W.D. (2018). Widespread loss of intermediate soil horizons in urban landscapes. Proceedings of the National Academy of Sciences, 115, 6751-6755.

Hope, D., Zhu, W., Gries, C., Oleson, J., Kaye, J., Grimm, N.B. et al. (2005). Spatial variation in soil inorganic nitrogen across an arid urban ecosystem. Urban Ecosystems, 8, 251-273.

Jackson, R.B., Banner, J.L., Jobbágy, E.G., Pockman, W.T. and Wall, D.H. (2002). Ecosystem carbon loss with woody plant invasion of grasslands. Nature, 418, 623-626.

Jenerette, G.D., Jianguo, W.U., Grimm, N.B. and Hope, D. (2010). Points, patches, and regions: Scaling soil biogeochemical patterns in an urbanized arid ecosystem. Global Change Biology, 12, 1532-1544.

Kaye, J., Majumdar, A., Gries, C., Buyantuyev, A., Grimm, N., Hope, D. et al. (2008). Hierarchical Bayesian scaling of soil properties across urban, agricultural, and desert ecosystems. Ecological Applications, 18, 132-145. 
Kuang, W. (2012). Spatio-temporal patterns of intra-urban land use change in Beijing, China between 1984 and 2008. Chinese Geographical Science, 22, 210-220.

Li, T., Zheng, W., Zhang, S., Jia, Y., Li, Y. and Xu, X. (2018). Spatial variations in soil phosphorus along a gradient of central city-suburb-exurban satellite. Catena, 170, 150-158.

Li, W., Ouyang, Z., Meng, X. and Wang, X. (2006). Plant species composition in relation to green cover configuration and function of urban parks in Beijing, China. Ecological Research, 21, 221-237.

Li, Z.G., Zhang, G.S., Liu, Y., Wan, K.Y., Zhang, R.H. and Chen, F. (2013). Soil Nutrient Assessment for Urban Ecosystems in Hubei, China. Plos One, 8, e75856.

Liu, R., Wang, M. and Chen, W. (2018). The influence of urbanization on organic carbon sequestration and cycling in soils of Beijing. Landscape and Urban Planning, 169, 241-249.

Liu, R., Wang, M., Chen, W. and Peng, C. (2016). Spatial pattern of heavy metals accumulation risk in urban soils of Beijing and its influencing factors. Environmental Pollution, 210, 174-181.

Liu, W., Ji, C., Zhong, J., Jiang, X. and Zheng, Z. (2007). Temporal characteristics of the Beijing urban heat island. Theoretical and Applied Climatology, 87, 213-221.

Lorenz, K. and Lal, R. (2009). Biogeochemical C and N cycles in urban soils. Environment international, $35,1-8$.

Lovett, G.M., Traynor, M.M., Pouyat, R.V., Carreiro, M.M., Zhu, W.-X. and Baxter, J.W. (2000). Atmospheric deposition to oak forests along an urban- rural gradient. Environmental science and technology, 34, 4294-4300.

Loya, W.M., Pregitzer, K.S., Karberg, N.J., King, J.S. and Giardina, C.P. (2003). Reduction of soil carbon formation by tropospheric ozone under increased carbon dioxide levels. Nature, 425, 705.

Lu, R. (2000). Soil agricultural chemical analysis method. China Agricultural Science and Technology Press, Beijing, 1-315.

Ma, X. (2007). Studies on soil and atmosphere environment in different green land in Beijing. MS thesis.

Mao, Q., Huang, G., Buyantuev, A., Wu, J., Luo, S. and Ma, K. (2014). Spatial heterogeneity of urban soils: the case of the Beijing metropolitan region, China. Ecological Processes, 3, 23.

Meng, Y., Cave, M. and Zhang, C. (2018). Spatial distribution patterns of phosphorus in top-soils of Greater London Authority area and their natural and anthropogenic factors. Applied Geochemistry, 88, 213-220.

Mo, W., Wang, Y., Zhang, Y. and Zhuang, D. (2017). Impacts of road network expansion on landscape ecological risk in a megacity, China: A case study of Beijing. Science of the Total Environment, 574, 1000- 
1011.

Peng, J., Zhao, S., Liu, Y. and Tian, L. (2016). Identifying the urban-rural fringe using wavelet transform and kernel density estimation: A case study in Beijing City, China. Environmental modelling and software, 83, 286-302.

Phillips, H.R., Guerra, C.A., Bartz, M.L., Briones, M.J., Brown, G., Crowther, T.W. et al. (2019). Global distribution of earthworm diversity. Science, 366, 480-485.

Phoenix, G.K., Emmett, B.A., Britton, A.J., Caporn, S.J., Dise, N.B., Helliwell, R. et al. (2012). Impacts of atmospheric nitrogen deposition: responses of multiple plant and soil parameters across contrasting ecosystems in long-term field experiments. Global Change Biology, 18, 1197-1215.

Polsky, C., Grove, J.M., Knudson, C., Groffman, P.M., Bettez, N., Cavender-Bares, J. et al. (2014). Assessing the homogenization of urban land management with an application to US residential lawn care. Proceedings of the National Academy of Sciences, 111, 4432-4437.

Pouyat, R., Groffman, P., Yesilonis, I. and Hernandez, L. (2002). Soil carbon pools and fluxes in urban ecosystems. Environmental pollution, 116, S107-S118.

Pouyat, R.V., McDonnell, M.J. and Pickett, S. (1995). Soil characteristics of oak stands along an urbanrural land-use gradient. Journal of Environmental Quality, 24, 516-526.

Pouyat, R.V., Szlavecz, K., Yesilonis, I.D., Groffman, P.M. and Schwarz, K. (2010). Chemical, physical, and biological characteristics of urban soils. Urban ecosystem ecology, 119-152.

Pouyat, R.V., Yesilonis, I.D. and Nowak, D.J. (2006). Carbon storage by urban soils in the United States. Journal of Environmental Quality, 35, 1566-1575.

Pouyat, R.V., Yesilonis, I.D., Russell-Anelli, J. and Neerchal, N.K. (2007). Soil Chemical and Physical Properties That Differentiate Urban Land-Use and Cover Types. Soilence Society of America Journal, 71, 1010.

Pouyat, R.V., Yesilonis, I.D., Szlavecz, K., Csuzdi, C., Hornung, E., Korsós, Z. et al. (2008). Response of forest soil properties to urbanization gradients in three metropolitan areas. Landscape ecology, 23, 11871203.

Raciti, S.M., Hutyra, L.R. and Finzi, A.C. (2012). Depleted soil carbon and nitrogen pools beneath impervious surfaces. Environmental Pollution, 164, 248-251.

Sharpe, D.M., Stearns, F., Leitner, L.A. and Dorney, J.R. (1986). Fate of natural vegetation during urban development of rural landscapes in southeastern Wisconsin. Urban Ecology, 9, 267-287. 
Su, Y., Wang, X., Wang, X., Cui, B. and Sun, X. (2019). Leaf and male cone phenophases of Chinese pine (Pinus tabulaeformis Carr.) along a rural-urban gradient in Beijing, China. Urban Forestry and Urban Greening, 42, 61-71.

Vasenev, V., Stoorvogel, J. and Vasenev, I. (2013). Urban soil organic carbon and its spatial heterogeneity in comparison with natural and agricultural areas in the Moscow region. Catena, 107, 96-102.

Wang, H.F., Qureshi, S., Knapp, S., Friedman, C.R. and Hubacek, K. (2015). A basic assessment of residential plant diversity and its ecosystem services and disservices in Beijing, China. Applied Geography, 64, 121-131.

Yu, H.Y., Li, T.X. and Zhang, X.Z. (2010). Nutrient budget and soil nutrient status in greenhouse system. Agricultural Sciences in China, 9, 871-879.

Yuan, D.G., Zhang, G.L., Gong, Z.T. and Burghardt, W. (2007). Variations of soil phosphorus accumulation in Nanjing, China as affected by urban development. Journal of Plant Nutrition and Soil Science, 170, 244-249.

Zhang, K., Xu, X.N., and Wang, Q. (2010). Characteristics of N mineralization in urban soils of Hefei, East China. Pedosphere, 20, 236-244.

Zhang, M. (2004). Phosphorus accumulation in soils along an urban-rural land use gradient in Hangzhou, southeast China. Communications in soil science and plant analysis, 35, 819-833.

Zhao, J. (2010). Species composition and spatial distribution of urban plants within the built-up areas of Beijing, China. PHD.

Zhao, J., Ouyang, Z., Zheng, H., Zhou, W., Wang, X., Xu, W. et al. (2010). Plant species composition in green spaces within the built-up areas of Beijing, China. Plant Ecology, 209, 179-179.

Zhao, Y.G., Zhang, G.L., Zepp, H. and Yang, J.L. (2007). Establishing a spatial grouping base for surface soil properties along urban-rural gradient-A case study in Nanjing, China. Catena, 69, 74-81.

Zhu, W.X. and Carreiro, M.M. (1999). Chemoautotrophic nitrification in acidic forest soils along an urbanto-rural transect. Soil Biology and Biochemistry, 31, 1091-1100.

Zhu, W.X. and Carreiro, M.M. (2004). Temporal and spatial variations in nitrogen transformations in deciduous forest ecosystems along an urban-rural gradient. Soil Biology and Biochemistry, 36, 267-278.

\section{Appendix}

Appendix The abbreviations of soil variables 


\begin{tabular}{|ll|}
\hline Abbreviations & Variable name \\
\hline SM & soil moisture \\
\hline SOC & soil organic carbon \\
SOM & soil organic matter \\
\hline NH4-N & soil ammonium-nitrogen \\
NO3-N & soil nitrate-nitrogen \\
\hline TN & soil total nitrogen \\
AP & soil available phosphorus \\
\hline TP & soil total phosphorus \\
AK & soil available potassium \\
\hline TK & soil total potassium \\
\hline Ca & soil calcium concentration \\
\hline Mg & soil magnesium concentration \\
\hline
\end{tabular}

\section{Figures}




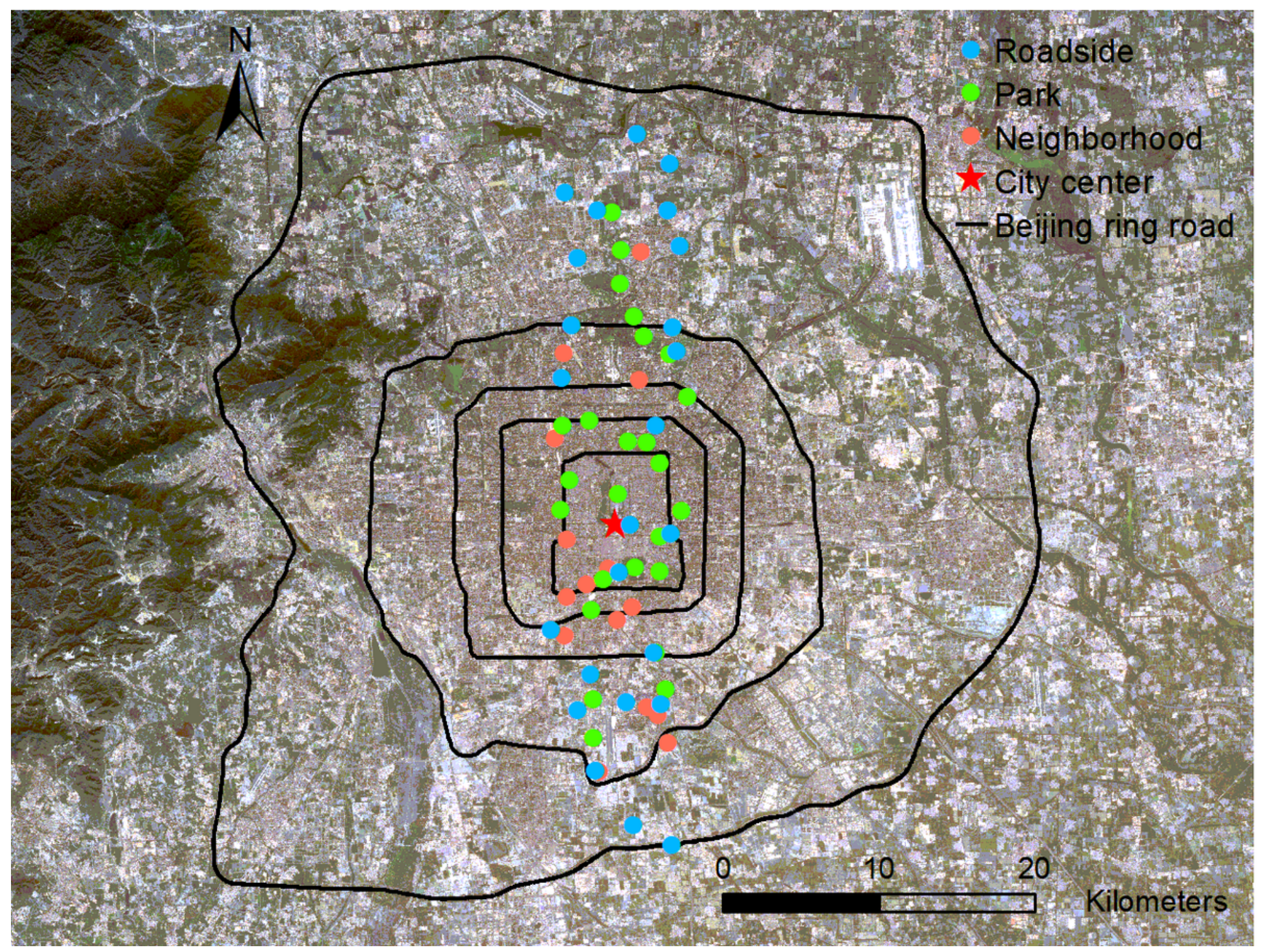

\section{Figure 1}

Study area and soil sampling sites. Note: The designations employed and the presentation of the material on this map do not imply the expression of any opinion whatsoever on the part of Research Square concerning the legal status of any country, territory, city or area or of its authorities, or concerning the delimitation of its frontiers or boundaries. This map has been provided by the authors. 


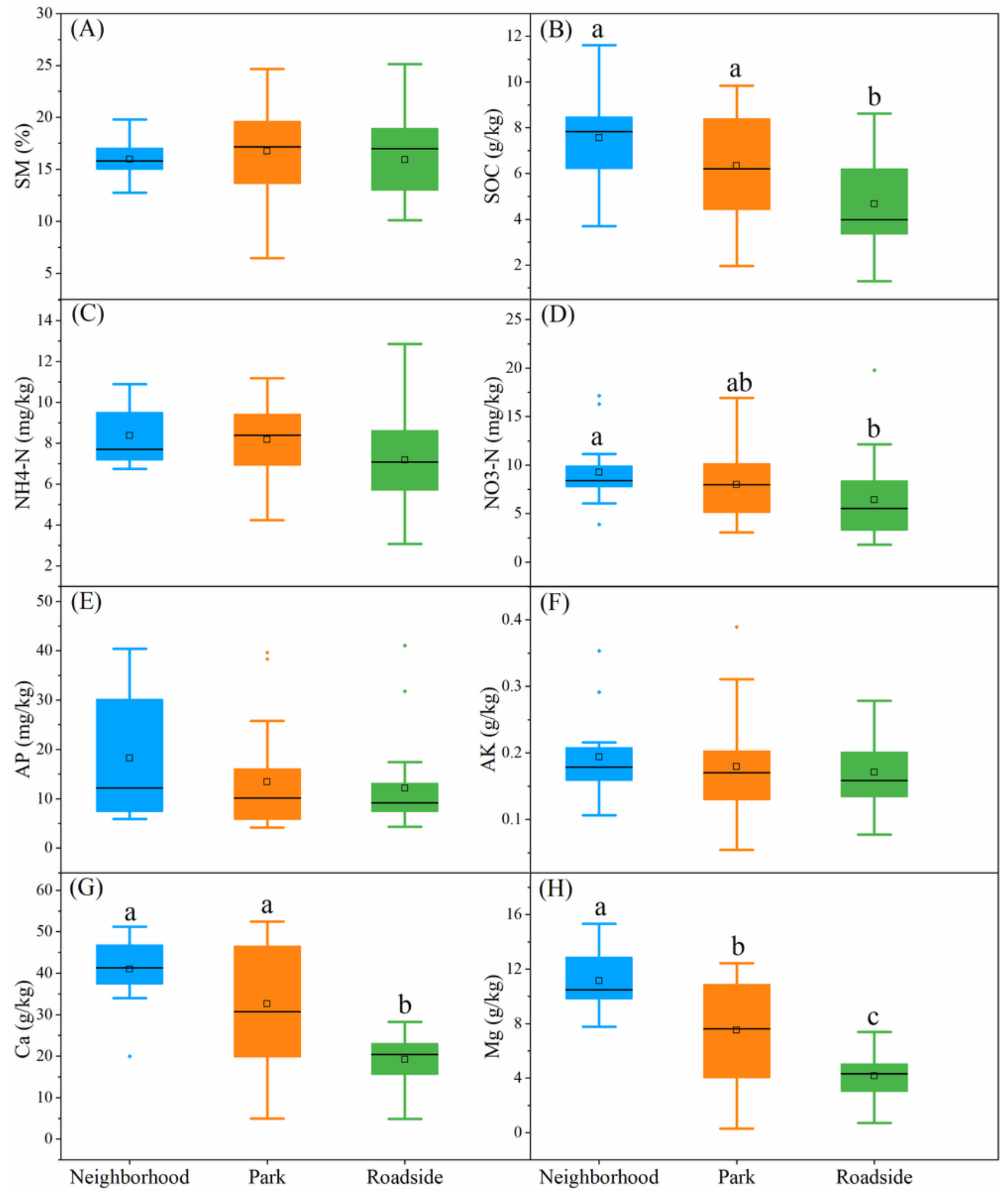

Figure 2

Differences in soil nutrients among land-use types. The letters indicated significant differences between land-use types at $\mathrm{P}<0.05$. The abbreviations of soil variables are shown in Appendix. 


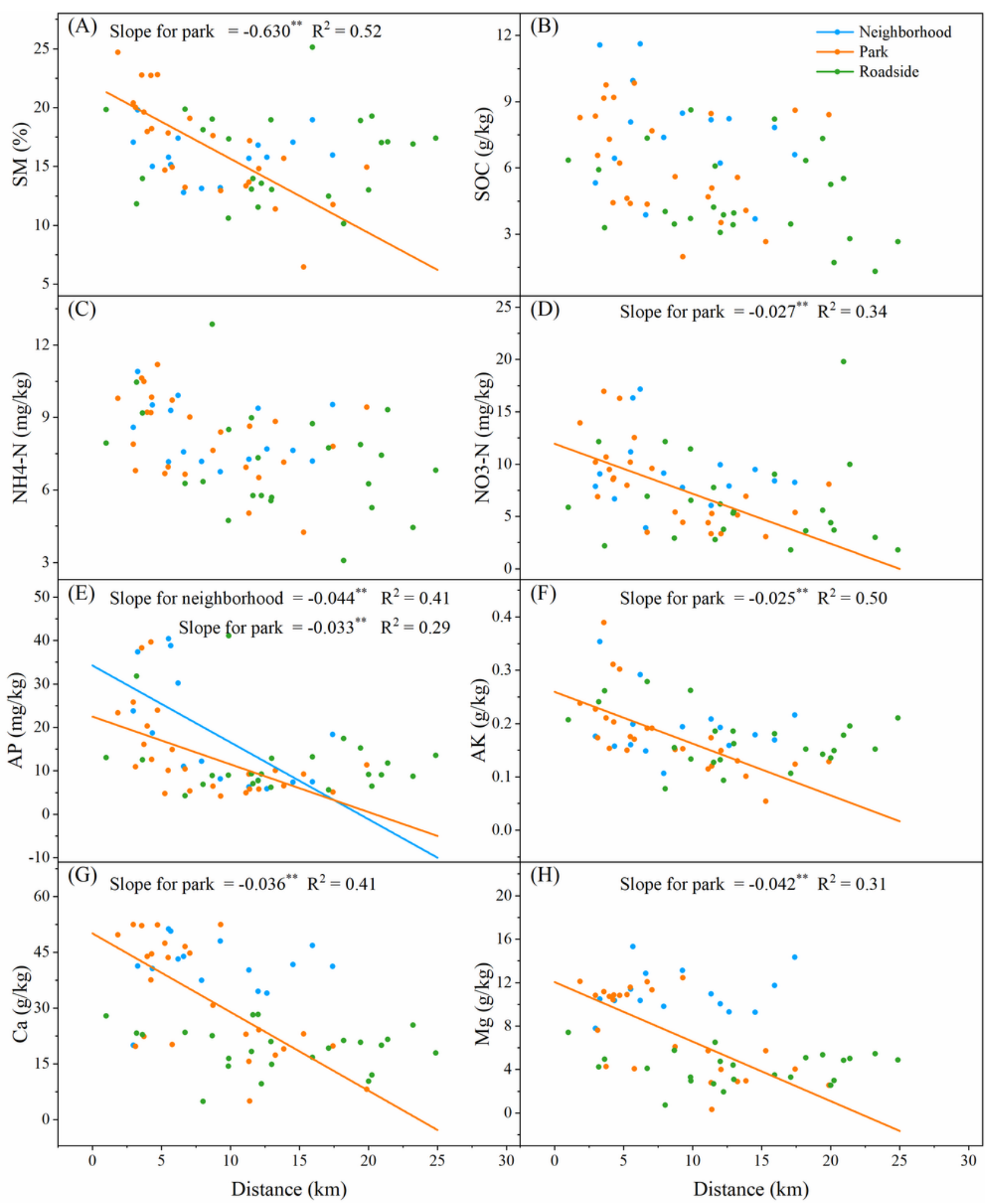

Figure 3

Changes of soil nutrients with the distance from city center for parks, neighborhoods and roadsides. Only were regressional lines showed when their relationships were significant $(P<0.05)$. * indicated the slope was significant at the level of $P<0.01$. The abbreviations of soil variables are shown in Appendix. 